\title{
Everything for sale? Neoliberalism and the limits of Michael Sandel's philosophical critique of
}

\section{$\underline{\text { markets }}$}

\section{$\underline{\text { Abstract }}$}

Contesting the central tenets of mainstream economic theory, Michael Sandel's work on markets argues that the marketization of certain goods risks corrupting the value of those goods, and that a reinvigorated public discourse is needed to establish the appropriate use of markets. This article assesses Sandel's work on markets, arguing that although it provides a convincing critique of liberal defenses of the market, it does not do enough to challenge marketization itself. To illuminate the flaws of Sandel's argument, the article contrasts it with Marxist critiques of neoliberalism, arguing that the latter oppose the expansion of markets and market thinking in more comprehensive and productive ways. Specifically, it is argued that Sandel: ignores the one market that underpins all other markets, namely the labor market; erroneously suggests that marketization is caused by the dominance of market thinking; and fails to appreciate the class interests that are served by growing marketization. The conclusion is not that Sandel should be abandoned, but rather that it is important to recognize the limitations of his philosophical framework for achieving the goal he sets himself, namely keeping markets in their place.

Keywords: Michael Sandel; markets; marketization; neoliberalism; Marxism; values; economics

\section{$\underline{\text { Introduction }}$}

For around forty years, a faith in free markets has played a significant and even predominant role in political practice and discourse. This has been reflected not only in the policies of privatization and deregulation that since the late-1970s governments across the world have pursued, but also in the increasing dominance of a certain way of thinking: an assumption that economic analysis can best explain human behavior and relations and that the market is the most appropriate mechanism for regulating human interactions. One of the many consequences of the economic crisis that began in 
2007 has been a widespread challenge to this faith in markets. ${ }^{1}$ The American philosopher Michael Sandel has referred to this post-crisis challenge as a move from "market triumphalism" to "market scepticism." ${ }^{2}$ Sandel has sought to develop a philosophical critique that both analyses the ways in which markets and market thinking have come to dominate almost every area of our lives and offers normative grounds for evaluating their use.

This article provides a critical assessment of Sandel's work on markets, as found in his 2012 book What Money Can't Buy: The Moral Limits of Markets and in a series of related essays. ${ }^{3}$ It argues that although Sandel's work should be celebrated for exposing both the increasing marketization of our lives and the often disavowed normative assumptions made by those who defend markets, his work has significant limitations. Ultimately, when Sandel asks us "to rethink the role that markets should play in our society," he does so not as a purely speculative exercise, but in order to help us

\footnotetext{
${ }^{1}$ Many of the most vocal critics have been students of Economics. In 2012 students at the University of Manchester formed the Post-Crash Economics Society in protest against their syllabus $<$ http://www.post-crasheconomics.com $>$ (last accessed June 16, 2016); they are affiliated to the umbrella group the International Student Initiative for Pluralism in Economics $<$ http://www.isipe.net $>$ (last accessed June 16, 2016). In 2011, students at Harvard University staged a walkout from an Economics class taught by Sandel's colleague Greg Mankiw (Jose A. DelReal, "Students Walk Out of Ec 10 in Solidarity with 'Occupy'," The Harvard Crimson [November 2, 2011] <http://www.thecrimson.com/article/2011/11/2/mankiw-walkout-economics-10/?page=1 > [last accessed June 16, 2016]).

${ }^{2}$ Michael Sandel, "Markets and Morals," Reith Lectures (June 9, 2009) $<$ http://downloads.bbc.co.uk/rmhttp/radio4/transcripts/20090609 reith.pdf $>$ (last accessed June 7, 2016).

${ }^{3}$ Michael J. Sandel, What Money Can't Buy: The Moral Limits of Markets (London: Allen Lane, 2012). It was in the mid-1990s that Sandel began to write directly about markets; many of those early essays are collected in Michael J. Sandel Public Philosophy: Essays on Morality in Politics (Cambridge, MA: Harvard University Press, 2005). The arguments were developed more fully in Sandel's Tanner Lectures and Reith Lectures - see Michael J. Sandel "What Money Can't Buy: The Moral Limits of Markets," in Grethe B. Peterson (ed.), The Tanner Lectures on Human Values, vol. 21 (Salt Lake City, UT: University of Utah Press, 2000), pp. 87-122 and Sandel, "Markets and Morals" - and have been refined and clarified in essays and responses written since the publication of What Money Can't Buy: see Michael J. Sandel, "Keeping Markets in Their Place," Boston Review (May/June 2012) $<$ http://www.bostonreview.net/forum/how-markets-crowd-out-morals/keeping-markets-theirplace> (last accessed June 7, 2016); Michael J. Sandel, "Michael J. Sandel Responds," The Hedgehog Review (Fall 2012), pp. 92-93; and Michael J. Sandel, "Market Reasoning as Moral Reasoning: Why Economists Should Re-engage with Political Philosophy," Journal of Economic Perspectives 27:4 (2013), pp. 121-140.
} 
address actually existing markets and to withstand and even reverse their expansion. ${ }^{4}$ But because his diagnosis of the problem that he identifies is partial and limited, focused primarily on philosophical justifications and critiques of markets rather than on the origins and functions of those markets themselves, he is unable to offer a strong enough challenge to the phenomena he describes. In order to highlight the shortcomings of Sandel's work and to suggest more effective ways of critically analyzing and resisting marketization, I compare his arguments with the work of a group of Marxist political economists, geographers, and cultural theorists. ${ }^{5}$ While Marxism may seem very far Sandel's interests, there is in fact significant overlap, for Marxist analyses of neoliberalism also interrogate the growing power of markets and market thinking - but they do so, I will argue, in more comprehensive, compelling, and productive ways.

The first section of this article explores the target of Sandel's critique. It argues that, although Sandel himself almost never uses the word, he is in effect analyzing neoliberalism, and it introduces the Marxist critique of neoliberalism. The second section examines Sandel's argument in detail. Finding problems with libertarian and utilitarian defenses of the market, Sandel distinguishes two different critiques of the market: a Rawlsian critique, which he finds too limited, and his own critique, which objects to markets on the basis that they can corrupt or degrade norms and values. I claim that the strength of Sandel's position lies in its exposure of the inherent normativity of market logic and its critique of the claim that markets and the terms in which they are defended can be morally neutral. The third section probes the weaknesses of Sandel's corruption argument by contrasting it with the Marxist critique of neoliberalism, focusing especially on the role of the labor

\footnotetext{
${ }^{4}$ Sandel, What Money Can't Buy, p. 7.

${ }^{5}$ In particular, I draw upon David Harvey, A Brief History of Neoliberalism (Oxford: Oxford University Press, 2005); Gérard Duménil and Dominique Lévy, Capital Resurgent: Roots of the Neoliberal Revolution, trans. Derek Jeffers (Cambridge, MA: Harvard University Press, 2004); Gérard Duménil and Dominique Lévy, The Crisis of Neoliberalism (Cambridge, MA: Harvard University Press, 2011); David M. Kotz, The Rise and Fall of Neoliberal Capitalism (Cambridge, MA: Harvard University Press, 2015); Andrew Glyn, Capitalism Unleashed: Finance, Globalization and Welfare (Oxford: Oxford University Press, 2006); Stuart Hall, "The Neo-Liberal Revolution," Cultural Studies 25:6 (2011), pp. 705-728; Greg Albo, Sam Gindin, and Leo Panitch, In and Out of Crisis: The Global Financial Meltdown and Left Alternatives (Oakland, CA: PM Press, 2010).
} 
market, the relation between markets and market thinking, and the ultimate causes of increasing marketization. The aim of the article is not to refute Sandel's entire argument or to call for its supersession by Marxism, but to highlight its flaws and to show that Sandel's goal of "keeping markets in their place" requires an analysis that is more radical and far-reaching than that which he offers. ${ }^{6}$ If we are to resist the subsumption of all aspects of life under the rule of the market, I argue, then we must recognize the class origins and effects of neoliberalism. This will entail moving beyond (but not abandoning) Sandel's philosophical analysis of markets in order to understand neoliberalism as a complex socio-economic phenomenon.

\section{Marketization or neoliberalism?}

Sandel is not a critic of the free market per se. Indeed, he thinks that "[n]o other mechanism for organizing the production and distribution of goods [has] proved as successful at generating affluence and prosperity." ${ }^{\prime 7}$ What concerns him is the increasing reach of markets into all areas of our lives: the way in which we have "drifted from having a market economy to being a market society. ${ }^{\prime \prime}$ He provides an exhaustive catalogue of examples of this marketization, that is, of the uses of market mechanisms and processes to organize and operate areas of life previously governed by non-market norms. These include: the privatization of goods and services; the introduction of markets and fees in place of regulations and fines; the use of financial incentives to influence behavior; the increasing prevalence of sponsorship and advertising; and the commercialization of personal relationships. ${ }^{9}$

Sandel's interest is not only in these practices of marketization, but in the forms of thinking by which they are legitimized or defended. He argues that as markets have spread further into our lives, so has "market reasoning" come to colonize our thinking. Economics has become "an imperial

\footnotetext{
${ }^{6}$ Sandel, What Money Can't Buy, p. 202.

${ }^{7}$ Ibid., 5.

${ }^{8}$ Ibid., 10.

${ }^{9}$ For examples of these practices see, respectively, ibid., 7, 65-79, 43-60, 163-203, 93-107.
} 
domain" as economists have recast their discipline as "a science of human behavior" in general, in which all conduct is interpreted in terms of the interactions of rational, calculating individuals within a market environment. ${ }^{10}$ Sandel is thinking here not just of the work of professional economists such as Gary Becker, but also of the wider popularization of this market logic in books such as Freakonomics. ${ }^{11}$

The object of Sandel's critique, then, is twofold: the increasing reach of both markets and market thinking. Given this, it is surprising that nowhere in his two hundred-page book does he mention the word "capitalism." While of course "markets" or even "free markets" are not synonymous with "capitalism," the use of markets is a necessary and defining feature of a capitalist economy, and all markets today operate within a domestic and global capitalist context: when we discuss marketization we are discussing the extension of capitalist social relations. Sandel might respond that his book is very clearly not a critique of capitalism as such. Defending the market as the most successful mechanism we have known for generating prosperity, he is really only interested in a particular aspect of capitalism, namely the relatively recent expansion of markets that has characterized the "era of market triumphalism" that began in the early $1980 \mathrm{~s} .{ }^{12}$ Yet this development is itself commonly referred to by another word that Sandel refuses to use: neoliberalism. ${ }^{13}$ Very many critics from a wide range of theoretical and political perspectives have defined neoliberalism as the extension of the market across society as a whole, and neoliberal theory as that which defends or rationalizes this extension by conceiving of all human relationships as market or market-like transactions.

\footnotetext{
${ }^{10}$ Ibid., 6, 48.

${ }^{11}$ Gary S. Becker, The Economic Approach to Human Behaviour (Chicago, IL: University of Chicago Press, 1976); Steven D. Levitt and Stephen J. Dubner, Freakonomics: A Rogue Economist Explores the Hidden Side of Everything (London: Penguin Books, 2006); see also Robert H. Frank, The Economic Naturalist: Why Economics Explains Almost Everything (London: Virgin Books, 2008) and Tim Harford, The Logic of Life: The Rational Economics of an Irrational World (New York, NY: Random House, 2008).

${ }^{12}$ Sandel, What Money Can't Buy, p. 6.

${ }^{13}$ As far as I can tell, the only place Sandel mentions neoliberalism is in passing in his Reith lectures (Sandel, "Markets and Morals").
} 
In this article I draw specifically on Marxist interpretations of neoliberalism, both because Marxists have been especially prolific and insightful commentators on neoliberalism and because their work provides convenient and pertinent points of intersection and contrast with that of Sandel. ${ }^{14}$ While Marxist perspectives on neoliberalism are of course varied - reflecting the diversity of Marxism itself - they find common ground in defining neoliberalism as the expansion and deepening of market relations and forces throughout society. ${ }^{15}$ In this way, Marxist analyses echo Sandel's interest in both markets and market thinking: they use the term "neoliberalism" to refer both to a set of economic policies and practices and to the theory that justifies those practices through the claim that all problems have a market solution. ${ }^{16}$ In short, what Marxists call "neoliberalism" looks very much like what Sandel calls "marketization": it is that which "seeks to bring all human action into the domain of the market."177 Neoliberalism entails what both Sandel and David Harvey call "the commodification of everything." ${ }^{\text {"18 }}$

Although the various Marxist critiques of neoliberalism are part of a broader critique of capitalism, their analyses tend to juxtapose neoliberalism not with a possible post-capitalist future but with the era of postwar capitalism immediately preceding neoliberalism. In other words, like Sandel they are interested in the novelty of a society dominated by markets, and like Sandel their aim is to think about how best to challenge and restrict markets. What distinguishes Marxists from Sandel, then, is not so much the object of their analyses or their goals, but rather their mode of analysis. In contrast to Sandel's philosophical investigation, Marxists have offered a socio-economic

\footnotetext{
${ }^{14}$ For a useful overview of different theoretical approaches to neoliberalism, see Kean Birch, "Neoliberalism: The Whys and Wherefores... and Future Directions," Sociology Compass 9:7 (2015), pp. 571-584. Notable non-Marxist analyses of contemporary neoliberalism include: Pierre Dardot and Christian Laval, The New Way of the World: On Neoliberal Society, trans. Gregory Elliott (London: Verso, 2013); Philip Mirowski, Never Let a Serious Crisis Go to Waste: How Neoliberalism Survived the Financial Meltdown (London: Verso, 2014); and Wendy Brown, Undoing the Demos: Neoliberalism's Stealth Revolution (New York, NY: Zone Books, 2015).

${ }^{15}$ See for example Albo et al., In and Out of Crisis, p. 16 and Kotz, Rise and Fall of Neoliberal Capitalism.

${ }^{16}$ M. C. Howard and J. E. King, The Rise of Neoliberalism in Advanced Capitalist Economies: A Materialist Analysis (Basingstoke: Palgrave Macmillan, 2008), p. 1.

${ }^{17}$ Harvey, Brief History of Neoliberalism, p. 3.

${ }^{18}$ Sandel, What Money Can't Buy, p. 9; Harvey, Brief History of Neoliberalism, p. 165.
} 
critique in which neoliberalism is figured as a "counter-revolution" against postwar social democracy. ${ }^{19}$ The period 1945-73, various Marxists argue, was an era of "regulated capitalism" or "tempered capitalism" characterized by "class compromise," whereby labor was protected and market forces were subject to numerous constraints (including state planning, demand management, capital controls, financial regulation, welfare provision, and consumer and employment rights). ${ }^{20}$ This compromise came under pressure in the 1970 s, when capital faced the combined challenges of intensified international competition, increasing trade union militancy, and a declining rate of profit. The social and economic crises of the 1970s provided capital with the motive and opportunity to reassert its power and profitability: it initiated an "unleashing of market forces" that overturned the postwar Keynesian consensus and saw the disembedding of capital from its prior constraints. ${ }^{21}$ This was achieved not through the rolling back of the state but through the use of the state to impose capital-friendly policies, typically including: a monetary strategy of high interest rates that aims at low inflation and price stability rather than full employment; fiscal discipline, privatizations, and cuts to business taxes and welfare; deregulation of industry, the financial sector, and consumer and employment protections and rights; and the lifting of barriers and restrictions to free trade and the international mobility of capital.

Most Marxist commentators would therefore agree with Harvey's definition of neoliberalism as "a political project to re-establish the conditions for capital accumulation and to restore the power of economic elites." ${ }^{22}$ I will argue that this very different approach to understanding and contesting markets - focused on socio-economic and political forces rather than philosophical debates - throws into relief some problems with Sandel's approach and highlight its limitations.

\footnotetext{
${ }^{19}$ Glyn, Capitalism Unleashed, p. 24; cf. David Harvey, "Neoliberalism Is a Political Project," Jacobin (July 23, 2016) <https://www.jacobinmag.com/2016/07/david-harvey-neoliberalism-capitalismlabor-crisis-resistance/> (last accessed October 13, 2016).

${ }^{20}$ Kotz, Rise and Fall of Neoliberal Capitalism; Duménil and Lévy, Crisis of Neoliberalism; Harvey, Brief History of Neoliberalism, p. 10.

${ }^{21}$ Glyn, Capitalism Unleashed, p. 130; Harvey, Brief History of Neoliberalism, p. 11.

${ }^{22}$ Harvey, Brief History of Neoliberalism, p. 19.
} 
Before we reach those limitations, however, we will need to examine Sandel's argument in some detail.

\section{$\underline{\text { Sandel's corruption argument }}$}

Sandel argues that the problem with some market exchanges is that they corrupt the good which is being exchanged, by degrading the values or meanings that we attach to the good. He distinguishes this position from three others. First, a libertarian position which defends markets on the basis that they reflect and enable individual freedom: if two consenting adults want to exchange something, then they should be free to do so. ${ }^{23}$ Second, a utilitarian position that defends markets on the basis that they increase social utility or welfare: if an exchange is consensual, then the position of both buyer and seller are by definition improved as a result of the exchange (if they were not, then the two parties would not enter into the exchange in the first place). ${ }^{24}$ Third, a Rawlsian position that criticizes the use of markets, but only if the background conditions of an exchange are marked by unfairness or inequality: if, for example, someone agrees to sell their kidney only because they need the money to feed their starving children then we could legitimately claim that one party has been coerced into the exchange. ${ }^{25}$

Sandel accepts the logic and importance of the Rawlsian critique but he considers it inadequate: it objects not to the use of market mechanisms as such, but only to the conditions under which they are used. It is, therefore, a contingent objection: it could not object to a market in kidneys (for example) in a society in which the conditions of exchange were fair (regardless of how "fairness" might be defined and assessed). ${ }^{26}$ Fundamentally, the Rawlsian critique agrees with the libertarian and utilitarian defenses that market exchanges are acceptable as long as they are

\footnotetext{
${ }^{23}$ Sandel, What Money Can't Buy, p. 29.

${ }^{24}$ Ibid., 125.

${ }^{25}$ Ibid., 45, 112, 186. Sandel himself does not explicitly identify this position as a Rawlsian one, but its central features reflect the discussions of Rawls found elsewhere in his work: see for example Michael J. Sandel, Liberalism and the Limits of Justice, $2^{\text {nd }}$ ed. (Cambridge: Cambridge University Press, 1998) and Michael J. Sandel, Justice: What's the Right Thing to Do? (London: Penguin, 2010). ${ }^{26}$ Sandel, What Money Can't Buy, p. 113.
} 
consensual: it is just that the Rawlsian argues that genuine consent can only be given under certain conditions. ${ }^{27}$ Sandel's counter-argument is that consent cannot be our only consideration. ${ }^{28}$ The question he thinks needs to be asked is not whether an exchange takes place under fair conditions (and hence whether it is "really" a consensual exchange at all), but whether an exchange dissolves or damages desired social norms or attitudes. ${ }^{29}$ According to this argument, the problem with a market in kidneys (to continue our example) is not primarily that under conditions of extreme poverty a person may be coerced into selling their kidney, but that such a market may violate or corrode attitudes that we value, as market relations crowd out non-market norms. ${ }^{30}$ It may, for example, encourage us to view our bodies merely as pieces of property from which we may profit, or it may undermine a shared belief that voluntary donations are the best way to distribute human organs. Sandel's objection to markets is thus much broader than the Rawlsian objection, because it "applies under conditions of equality and inequality alike." ${ }^{31}$

The strength of Sandel's corruption argument is the way in which it challenges the supposed neutrality of both markets and market thinking. Within the discipline and literature of Economics, the defense of markets is often formulated using the terminology of "efficiency" or "rationality." Sandel expertly elicits the normative assumptions that underlie this putatively "neutral" language by showing, for example, that when economists defend the "efficiency" of a market they are implicitly making a utilitarian claim: "efficiency" refers to the ability of markets to maximize the satisfaction of individual preferences by allocating goods to those who value them most. ${ }^{32}$ In addition, he subverts the claim that market exchanges themselves are neutral. For libertarians, utilitarians, and Rawlsians, markets are neutral in the sense that they simply allocate goods according to people's freely chosen

\footnotetext{
${ }^{27}$ Cf. Michael J. Sandel, Democracy's Discontent (Cambridge, MA: Harvard University Press, 1996), pp. 51-2, 184, 330.

${ }^{28}$ Sandel, "What Money Can't Buy," p. 122.

${ }^{29}$ Sandel, What Money Can't Buy, p. 110.

${ }^{30}$ Sandel, "Market Reasoning as Moral Reasoning," p. 124.

${ }^{31}$ Sandel, What Money Can't Buy, p. 111.

32 Ibid., 29, 88.
} 
preferences, without judging those preferences. ${ }^{33}$ Indeed, this is often taken to be the central advantage of markets: in a world of moral and cultural diversity, the appeal of the market is that individuals are left free to choose their own ends, without the need for any agreement over what are our common values or what is the common good of society.

To use an example: prostitution can be defended by a libertarian on the basis that consenting adults should be able to buy or sell sex, or by a utilitarian on the basis that the exchange increases social utility (by "satisfying" both the sex worker and her client). A Rawlsian may object to prostitution, but only if it takes place under unfair conditions (if, for example, the sex worker has been coerced into her job through economic necessity). All three will claim that they make no judgment about the morality of prostitution and that individuals should be free to choose their own ends. But inherent in this argument is an unavoidably normative claim that sex is the sort of thing that can be bought or sold. To argue that prostitution is merely a matter of mutual consent is not to remain morally neutral; rather, it is to defend the moral position that individual freedom of choice is more important than any other consideration. Hence other moral positions - for example, the notion that the commercialisation of sex corrupts the meanings or values that we associate with sex, or that it demeans women by treating them as commodities rather than as equal citizens - are tacitly rejected.

For Sandel, the supposed "neutrality" of markets is therefore specious. Given that the terms with which markets are defended - liberty, welfare, fairness, efficiency, and so on - are necessarily normative and express some vision of the good life, any assessment of markets must refer (albeit often implicitly) to some conception of the good life. Moreover, markets themselves are never neutral: rather than simply distributing goods more or less efficiently, markets "reflect and promote certain norms, certain ways of valuing the goods they exchange." ${ }^{34}$ As such, markets can corrupt the values and norms that we attach to those goods. They can even alter the good itself, and not merely

\footnotetext{
33 Ibid., 48.

${ }^{34}$ Ibid., 78.
} 
its surrounding norms or attitudes: sex that is bought on the market, for instance, is surely not the same as sex that is freely entered into. It is off course true that the values and meanings of goods are a matter of dispute, and hence whether or not a good has been "corrupted" by a market will be up for debate. (Is sex "corrupted" when it is bought and sold in a market?) But this is exactly Sandel's point: in order to assess the appropriate use and scope of markets, we must necessarily discuss the meaning and purpose of the goods that are exchanged. Far from allowing us to distribute goods and services without reference to our common values, for Sandel the market demands that we debate our concepts of the good - because without that debate we cannot establish which values and norms we want to protect from market corruption.

It can be seen that Sandel's work on markets reflects themes and arguments in his earlier writings. It is (notwithstanding Sandel's ambivalence about the term) communitarian insofar as it rejects liberal claims for the possibility and desirability of neutrality, instead insisting on the need to reflect on our common values. ${ }^{35}$ It is neo-Aristotelian insofar as it asks us to consider the meaning or purpose of goods. Finally, it is republican insofar as it recognizes that the meaning of goods is not fixed by nature but can only be established through public and democratic deliberation. ${ }^{36}$

\section{Criticizing Sandel}

Critics of Sandel have tended to focus on the normative aspect of his critique, either by protesting that markets are normatively neutral, by insisting that the study of markets requires an empirical or evidential rather than a normative approach, or by arguing that Sandel ignores the inherent

\footnotetext{
${ }^{35}$ On Sandel's ambivalence about identifying as a communitarian, see Sandel, Liberalism and the Limits of Justice, p. ix; Michael J. Sandel, "On Republicanism and Liberalism: Interview by Leif Weiner and Chong-Min Hong," The Harvard Review of Philosophy (Spring 1996), p. 67. His argument about marketization echoes other "communitarian" interventions into debates on markets, not least Michael Walzer, Spheres of Justice: A Defense of Pluralism and Equality (New York, NY: Basic Books, 1983). See also Elizabeth Anderson, Value in Ethics and Economics (Cambridge, MA: Harvard University Press, 1993) and Margaret Jane Radin, Contested Commodities (Cambridge, MA: Harvard University Press, 1996).

${ }^{36}$ Sandel, What Money Can't Buy, p. 202; Sandel, “What Money Can't Buy," pp. 106-107.
} 
contestability of norms. ${ }^{37}$ In contrast, my argument is that the central advantage of Sandel's approach is precisely the philosophical sophistication with which it reveals the normative assumptions hidden within the market logic of mainstream economics, extending his earlier critique of (a certain kind of) liberalism to include the prevailing forms of contemporary liberal economic thought. This strength is also a weakness, however, for Sandel tends to proceed as if opposing markets means simply criticizing liberal ways of thinking about markets and developing alternative ways of thinking. But as elegant and convincing as is Sandel's philosophical critique, the goal that he sets himself - of "keeping markets in their place" - requires that we "leave philosophy aside" (to borrow from Marx and Engels) and attempt to engage in a more historically and sociologically informed manner with the political and economic realities of markets. ${ }^{38}$ This is exactly what various Marxists have done in their critiques of neoliberalism. I will now use those critiques to illuminate some of the flaws and lacunae in Sandel's position.

The missing market: labor

Although he offers a plethora of examples to demonstrate the increasing reach of markets in our lives, Sandel nevertheless underestimates that reach in various ways. In the first place, he has a tendency to treat markets as if they are distinct spheres unconnected to each other. Within the logic of his argument, this makes sense: our assessment of the appropriateness of markets must for

\footnotetext{
${ }^{37}$ For these arguments, see, respectively, Elaine Sternberg, "What Money Can Buy: Michael Sandel's Intuitions of Injustice and Inferiority," Economic Affairs 33:3 (2013), pp. 391-399; Samuel Bowles, "How Markets Crowd In Morals," Boston Review (May/June 2012) $<$ http://www.bostonreview.net/bowles-markets-crowd-in-morals $>$ (last accessed June 8, 2016) and Herbert Gintis, "Giving Economists Their Due," Boston Review (May/June 2012) $<$ http://www.bostonreview.net/gintis-giving-economists-their-due> (last accessed June 8, 2016); Debra Satz, Why Some Things Should Not Be for Sale: The Moral Limits of Markets (Oxford: Oxford University Press, 2010), pp. 79-84 and Eva Illouz, "Does Money Undermine Social Relations?" The Hedgehog Review (Fall 2012), pp. 89-90. In response to the final criticism concerning the contestability of norms, Sandel makes it clear that he is not trying to establish "a general principle that can tell us, once and for all, which goods should be bought and sold on the market" but is rather inviting us to "engage in moral deliberation and political debate about how these goods are properly valued" (Sandel, "Michael J. Sandel Responds," pp. 92-93).

${ }^{38}$ Karl Marx and Friedrich Engels, The German Ideology, in Karl Marx and Friedrich Engels, Collected Works Volume 5 (London: Lawrence and Wishart, 1976), p. 236.
} 
Sandel take place on a case-by-case basis, because different goods have different purposes or meanings and those purposes and meanings will be affected in different ways by marketization. But proceeding in this manner tends to obscure the interconnections between markets and the reliance of non-market activities on markets.

In particular, and most significantly, Sandel never mentions the one market that underpins all the others within any capitalist society, namely the labor market. This omission undermines his ability to understand the scope and significance of marketization. In contrast, in Marxist analyses of neoliberalism the issues of labor and the labor market are central. This is to be expected, given that for Marx the simple exchange of commodities that takes place in the marketplace is merely "the surface process, beneath which, however, in the depths, entirely different processes go on": if we are to understand market exchanges, then we must descend to the "depths" of production and examine the exchange between labor and capital. ${ }^{39}$ Doing so, Marx claims, exposes the exploitative nature of the relation between labor and capital, revealing that the supposedly free and equal exchanges of the market are "only the surface layer of a production which rests on the appropriation of alien labour without exchange, but with the semblance of exchange." ${ }^{\prime 40}$

But there is a more specific reason why Marxist critics of neoliberalism pay special attention to the labor market, and that is because for Marxists the basic goal of neoliberalism - the restoration of profitability - is achieved through the reassertion of the power of capital over labor. What this has meant in practice is an ever more intense submission of labor to the powers and principles of the market. This is partly an effect of neoliberal policies of fiscal discipline, privatization, deregulation, free trade, and increased competition, all of which have contributed to stagnating and falling wages and increased unemployment, and hence the weakening of labor. But neoliberalism has also operated through direct assaults on labor, including legislative attacks on trades unions, cuts to

\footnotetext{
${ }^{39}$ Karl Marx, Grundrisse: Foundations of the Critique of Political Economy (Rough Draft), trans. Martin Nicolaus (London: Penguin Books, 1973), p. 247.

${ }^{40}$ Ibid., 509.
} 
welfare, and the restriction of employment rights. ${ }^{41}$ These assaults amount to an erosion of the nonmarket forms of collective solidarity and social protection from which workers benefitted in the era of tempered capitalism. As Harvey has put it: "Neoliberalization seeks to strip away the protective coverings that embedded liberalism allowed and occasionally nurtured." ${ }^{42}$ Yet neoliberalism has not only removed the protections that guarded workers against the excesses of the market and compensated for its pernicious effects. It has also imposed market norms and values in the workplace itself: financial incentives are used to encourage certain behaviors from employees; jobs have been "casualized", with workers increasingly hired as self-employed freelancers or contractors on fixed-term and insecure contracts; and employees are encouraged and even commanded to act according to market norms such as flexibility, efficiency, profitability, and accountability, in place of more traditional non-market values such as solidarity, loyalty, and professional judgment.

Aside from a passing mention of performance-related pay for teachers (in the context of a discussion of bribing students to read books), these developments are overlooked by Sandel. ${ }^{43}$ It might be argued that his omission of the labor market is relatively inconsequential for his overall argument. Yet the labor market is central to what Sandel calls our "market society": not only does it underpin all other markets, it is through the labor market that most of us experience the impacts of marketization most acutely (because we cannot earn a living without actively partaking in these particular forms of marketization). The absence of any mention of the labor market in What Money Can't Buy is especially striking because elsewhere Sandel discusses it in detail. In Democracy's Discontent he shows how nineteenth-century American republicans objected to wage-labor on the basis that it undermined the capacity for self-government: by producing poverty and dependence (it was argued), wage-labor corrupted or degraded labor's potential to cultivate the moral and civic qualities required for active citizenship. ${ }^{44}$ This perspective takes Sandel's corruption argument in a

\footnotetext{
${ }^{41}$ Glyn, Capitalism Unleashed, chapter 5.

${ }^{42}$ Harvey, Brief History of Neoliberalism, p. 168.

${ }^{43}$ Sandel, What Money Can't Buy, pp. 53-54.

${ }^{44}$ Sandel, Democracy's Discontent, pp. 168-200.
} 
potentially revolutionary direction (for if we preclude the buying and selling of labor then capitalism cannot function), which perhaps explains why he is so reluctant to discuss the labor market in What Money Can't Buy: he is unwilling to contemplate the radical consequences of questioning the meaning and value of labor. Yet the assumption that the labor market cannot or should not be questioned is strictly speaking not warranted by the logic of his argument, and his failure to address the one market that is the condition of all others means that Sandel ignores many of the worst excesses of marketization and tends to decontextualize its development. Moreover, Sandel could have challenged neoliberal "reforms" to the labor market without necessarily calling for an end to wage-labor: even some Marxists have prioritized the restoration of non-market labor protections over the abolition of the labor market. ${ }^{45}$

\section{Market thinking or neoliberal ideology?}

Sandel is clear that the phenomenon of marketization has increased in recent years, but he gives little indication of why this has happened. He connects it to the increasingly imperialistic ambitions of the discipline of Economics and its predominant market logic, but the precise nature of this connection is unclear. He argues that the spread of markets and the rise of market reasoning are reinforcing tendencies that have occurred "[a]t the same time.." ${ }^{\prime 6}$ But has one led to the other? Does one have priority over the other? Or is there a third factor causing them both? Sandel does not directly say, but his focus on values encourages the conclusion that marketizaton is an application or consequence of market thinking: if we have a society dominated by markets, it is because we have allowed our common values and norms to be crowded out by market values and norms. Our social relations have been remade "in the image of market relations" such that "the economic way of thinking... is coming to be true." ${ }^{47}$ This interpretation of Sandel's work is encouraged by many of his examples. In a discussion of market solutions to immigration policy, for instance, Sandel notes that

\footnotetext{
${ }^{45}$ This is especially true of Harvey, Brief History of Neoliberalism.

${ }^{46}$ Sandel, "Michael J. Sandel Responds," p. 92; Sandel, What Money Can't Buy, p. 48.

${ }^{47}$ Sandel, What Money Can't Buy, pp. 51, 104.
} 
in the mid-1980s the economist Julian L. Simon proposed selling the right to immigrate to the United States; by 1990 Congress had in effect enacted this proposal by allowing entry to foreigners who were willing to invest five hundred thousand dollars in the country. ${ }^{48}$

But giving precedence to ideas and values in this way is dubious not only because it affords undue power to professional economists and their ability to influence public opinion, but also because it tells us nothing about the conditions under which market thinking was developed or disseminated. Why did economists start to think that market logic could be applied to all areas of life? By what means were their ideas then circulated? Why were those ideas so widely accepted and endorsed, in particular by policy-makers?

From a Marxist perspective, Sandel's prioritization of ideas over practices gets things the wrong way round: market thinking must be understood as an element of neoliberal ideology, which reflects and justifies neoliberal policies and practices rather than motivating and shaping them. Most Marxists would agree with Sandel that "the economic way of thinking" has become a kind of common sense. But, as Stuart Hall and others have argued, it is important to recognize the extent to which this common sense has been deliberately constructed as part of the hegemonic project of neoliberalism. ${ }^{49}$

Conceptualizing "market thinking" as neoliberal ideology facilitates a more nuanced analysis of the origins, content, durability, efficacy, and function of such thinking and better allows us to relate it to the expansion of markets in practice. If market thinking has been effective, it is in part because it has rarely been advocated in a "pure" form, but has been mixed with elements of popular common sense and existing principles and ideals. The market logic of Thatcherism, for example, was part of a sometimes unstable ideological package that also contained traditional conservative concerns with authority, law and order, and moral cohesion as well as populist appeals to national

\footnotetext{
48 Ibid., 62.

${ }^{49}$ Hall, "Neo-Liberal Revolution"; Harvey, Brief History of Neoliberalism, chapter 2; Apeldoorn and Overbeek, "Introduction."
} 
identity and imperial nostalgia..$^{50}$ Neoliberal ideology is in this way often a mix of contradictory elements. But it is also often in contradiction with neoliberal practices. In theory, for example, neoliberalism has advocated the rolling back of the state to allow the invisible hand of the market to flourish. In practice, however, neoliberalism has relied heavily on a highly active and interventionist state to establish, regulate, and maintain markets. State interference becomes even more obvious at times of economic crisis, when the theory is abandoned entirely and governments step in with bailouts, nationalizations, stimulus packages, and so on. ${ }^{51}$

The flexibility and adaptability of neoliberal ideology and the ways in which it is ignored or jettisoned when it comes into conflict with neoliberal practice suggest that ideas are less important than Sandel claims. While it has played an important role in rationalizing and normalizing market relations, market thinking is not itself behind the expansion of markets. In many cases, in the Global South in particular, markets have simply been violently imposed on populations. Even in the neoliberal heartland of the U.S., populations have acceded to marketization not primarily because they have been persuaded or deceived by market logic but because they are highly integrated into and dependent upon markets. This is especially true of the expansion of financial markets that has been a central component of neoliberalism: as workers, consumers, and homeowners, people have a vested interest in the continued and healthy functioning of financial markets, because their pensions, credit cards, and mortgages are tied up in those markets. ${ }^{52}$ Markets can compel us to act in certain ways, or at least compromise our actions, regardless of the thoughts and beliefs in our heads. A good example here is (unintentionally) provided by Sandel himself. Videos of Sandel's Harvard lectures on justice are provided online. ${ }^{53}$ But before watching a lecture, the viewer is treated to a message thanking funders and sponsors, who include The Goldman Sachs Foundation and POM Wonderful pomegranate juice. Harvard itself is already a highly commercialized institution,

\footnotetext{
${ }^{50}$ Hall, “Neo-Liberal Revolution,” p. 713.

${ }^{51}$ Harvey, Brief History of Neoliberalism, chapter 3; Albo et al., In and Out of Crisis.

${ }^{52}$ Albo et al., In and Out of Crisis.

${ }^{53}<$ http://www.justiceharvard.org $>$ (last accessed June 16, 2016)
} 
charging many students almost sixty thousand dollars per year for the privilege of studying there. The point here is not that Sandel is somehow a hypocrite (given that he does not have responsibility for either the sponsorship of his lectures or Harvard's entrance policies). But the example suggests that even those who are committed to challenging the spread of markets can find themselves unwillingly promoting and participating in markets that they would otherwise condemn.

Pace Sandel, therefore, market thinking is secondary to marketization, rather than its origin or cause. As such, simply challenging market thinking is unlikely to achieve Sandel's ultimate aim of preventing or reversing the proliferation of markets themselves. To do so, we need to think about the causes of marketization, to which we now turn.

\section{Societal drift or class project?}

Sandel claims that "without quite realizing it, without ever deciding to do so, we drifted from having a market economy to being a market society." ${ }^{54}$ From a Marxist perspective, this is naïve: the claim that "we" have "drifted" towards marketization obscures significant social divisions and underplays the deliberateness with which markets have been created and promoted. Many Marxists have argued that if we are to challenge the dominance of markets - which is also ultimately Sandel's aim - then we need to think about the origins of marketization, which in turn means thinking about who benefits from marketization. As the Marxist economists Gérard Duménil and Dominique Lévy have put it (slightly melodramatically), we need to ask, "Who benefits from the crime?"55 Their answer is clear: neoliberalism has seen a huge transfer of power and wealth away from labor and towards the upper echelons of the capitalist classes, in particular finance capital. "[W]hat neoliberalism did to the benefit of a minority is what this minority... strived to achieve," namely the restoration of profits and high incomes for an economic elite..$^{56}$

\footnotetext{
${ }^{54}$ Sandel, What Money Can't Buy, p. 10.

${ }^{55}$ Duménil and Lévy, Capital Resurgent, chapter 15.

${ }^{56}$ Duménil and Lévy, Crisis of Neoliberalism, p. 126.
} 
Duménil and Lévy are careful to pre-empt possible accusations that they view neoliberalism as the product of a bourgeois conspiracy. They stress that the question of who benefits from neoliberalism is not identical to the question of how neoliberalism developed: the end product does not tell us all we need to know about the origins. ${ }^{57}$ Those origins are complex and diffuse, with causal factors including long-term historical forces, geopolitical rivalries, and technological change as well as deliberate decisions taken by specific agents. Neoliberalism is never simply the result of a carefully executed plan; as Harvey puts it, "[t]he capitalist world stumbled towards neoliberalization... through a series of gyrations and chaotic experiments. ${ }^{58}$ Moreover, the global implementation and development of neoliberalism has been varied and uneven, influenced by innumerable local determinations. ${ }^{59}$ Nonetheless, in its production and reinforcement of certain patterns of wealth and power, the growth of markets under neoliberalism has clearly served particular interests, and those interests have been aggressively and consciously pursued and defended by the beneficiaries of neoliberalism.

In contrast, Sandel proceeds as if marketization does not have differential consequences but affects us all equally. His focus is on how markets can threaten our common values: how we as a community understand the values of different goods and how markets can corrupt those values. This essentializing approach to community can also be found in Sandel's earlier work, which was criticized for suppressing the pluralism of modern societies and excluding any notion of otherness that might challenge our identity and values. ${ }^{60}$ But the issue here is not so much about the value pluralism of modern societies or about where we draw the boundaries of our community (and hence how the "we" is constituted) but rather about the existence within any community of conflicting material interests - the existence, in other words, of class divisions.

\footnotetext{
${ }^{57}$ Duménil and Lévy, Capital Resurgent, p. 212.

${ }^{58}$ Harvey, Brief History of Neoliberalism, p. 13.

${ }^{59}$ Ibid., chapter 4; Apeldoorn and Overbeek, "Introduction", pp. 8-9. In general, the global reach of Marxist analyses is in contrast to Sandel's somewhat parochial focus on the U.S.

${ }^{60}$ Chantal Mouffe, The Return of the Political (London: Verso, 2005), pp. 31-32, 46-47; Bonnie Honig, Political Theory and the Displacement of Politics (Ithaca, NY: Cornell University Press, 1993), pp. 162199.
} 
Sandel views markets and marketization not as representing or furthering particular interests, but as a potential threat to the common good. The way to protect that common good, he argues, "is to deliberate openly and publicly about the meaning of the goods and social practices we prize. ${ }^{\prime 61}$ Yet there are several reasons to doubt the efficacy of public deliberation in resisting the expansion of markets. If, as most Marxists argue, markets embody and advance class interests, then there is likely to be fierce opposition by the holders of those interests to any attempt to restrict markets. Moreover, the very spaces in which public deliberation usually occurs - newspapers, television, radio, digital social media, even our streets and public squares - are themselves frequently dominated by those class interests and are already highly marketized. As we have already seen, even the spaces in which Sandel himself discusses the moral limits of markets are themselves deeply marketized.

This is not to argue, of course, that we must pessimistically resign ourselves to the permanence and ineradicability of markets or to the unassailable triumph of neoliberalism. Different countries have adopted neoliberalism in different ways and to varying extents, and in many places it has faced vigorous resistance and consequent setback and reversals. "[N]eoliberalism is a project in motion, continuously contested, a process of countless rounds of struggles and negotiations with oppositional forces." ${ }^{62}$ But successful opposition to markets has tended to involve fierce and sometimes violent "struggles between contending social forces," rather than attempts to persuade others through rational argumentation or by debating our common values. ${ }^{63}$ This does not mean that the kind of democratic debate which Sandel advocates is irrelevant, but to posit it as the solution to increasing marketization is at best partial and surely underestimates the power of markets and the interests that they serve.

\section{Conclusion}

\footnotetext{
${ }^{61}$ Sandel, What Money Can't Buy, p. 202.

${ }^{62}$ Apeldoorn and Overbeek, "Introduction," p. 6.

${ }^{63}$ Ibid., 12.
} 
I have argued that contrasting Marxist critiques of neoliberalism with Sandel's philosophical interrogation of markets illuminates some of the flaws of the latter. Specifically, Sandel: ignores the most important market of all, namely the labor market; mistakenly portrays market thinking as a cause of marketization; and misleadingly frames the spread of markets as a problem of "drift" that can be rectified through democratic debate. In contrast, by understanding marketization as an aspect of neoliberalism, Marxists: foreground the imposition of market principles and practices within the labor market; situate market thinking and the imperialism of Economics within neoliberal ideology, which may facilitate but does not cause neoliberal practice; and identify marketization as part of a broader class project that has specific objectives and beneficiaries and which has been most often resisted through class struggle rather than public debate. If marketization is to be challenged, then we will need to move beyond Sandel's philosophical framework: rather than focusing on the common good and consensus, we need to examine the social and economic divisions that have produced and been exacerbated by marketization; rather than discussing values - whether the values of the market or the values threatened by the market - we must turn to questions of power, ownership, and control.

In general, Sandel's work on markets highlights some of the strengths and limitations of his work as a whole. Like the earlier work, What Money Can't Buy eloquently demonstrates both the dominance and the weaknesses of a certain liberal conception of the self as an individual freely choosing her own ends, as well as associated assumptions about the possibility and desirability of maintaining neutrality between different conceptions of the good. But whereas it was plausible to argue (as Sandel did in earlier writings) that these liberal assumptions had marginalized and undermined an alternative tradition of civic republicanism and even contributed to a corrosion of public life, such a claim becomes much less plausible when applied to marketization: liberal assumptions and arguments have certainly played a role in justifying and defending markets, but they cannot explain their increasing scope and influence. For such an explanation, I have suggested, we are better off turning to Marxist critiques of neoliberalism. Sandel's defense of the community in 
the face of the marketization undermining "our" values fails to acknowledge that any and every community is divided on class lines. It is only by reflecting on the role of class - and the class interests that have driven and benefitted from marketization - that we have any hope of keeping markets in their place. 